http://dx.doi.org/10.12775/szhf.2016.028

\author{
Joanna Dorota ZegzuŁa-NowaK \\ Uniwersytet Zielonogórski, Zielona Góra, Polska \\ JOANNA_ZEGZULA@VP.PL
}

\title{
Henryk Elzenberg w świetle nieznanych źródeł archiwalnych Mieczysława Wallisa
}

Henryk Elzenberg i Mieczysław Wallis to wybitne postaci rodzimej humanistyki.

Jako domenę swej aktywności twórczej Elzenberg wybrał filozofię kultury, krytykę literacką oraz aksjologię, której naczelne filary upatrywał w etyce i estetyce. Był on filozofem niezależnym, można by nawet rzec - w swej twórczości hermetycznym ${ }^{1}$. Konsekwentnie podążał własną myślową ścieżką, nie bacząc na ówczesne prądy kulturowo-intelektualne.

Z kolei Mieczysław Wallis był wychowankiem filozoficznej szkoły lwowsko-warszawskiej, jednym z najbliższych uczniów, a następnie współpracowników naukowo-akademickich Tadeusza Kotarbińskiego ${ }^{2}$. Zajmował się

\footnotetext{
${ }^{1}$ Por. R. Palacz, Klasycy filozofii polskiej, Zachodnie Centrum Organizacji, Warszawa-Zielona Góra 1999, s. 328.

${ }^{2}$ Początkowo T. Kotarbiński był nauczycielem akademickim M. Wallisa na Uniwersytecie Warszawskim, gdzie studiował on filozofię. Następnie obaj uczeni byli współpracownikami naukowo-dydaktycznymi na utworzonym po wojnie Uniwersytecie Łódzkim.
} 
przede wszystkim krytyką artystyczną, estetyką, historią i teorią sztuki ${ }^{3}$. Co ważne, był on jednym $\mathrm{z}$ najbliższych przyjaciół Henryka Elzenberga.

\section{Archiwalia Mieczysława Wallisa jako źródło wiedzy o Henryku Elzenbergu}

Mieczysław Wallis pozostawił po sobie niezwykle bogatą i obszerną spuściznę rękopiśmienną (zawierającą kilka tysięcy stron), nie jest ona jednak znana szerszemu gronu. Nie została też dotychczas wydana. Bywa jedynie fragmentarycznie cytowana $w$ nielicznych dziełach monograficznych jemu poświęconych (na przykład przez Teresę Pękalę) ). Spuścizna Wallisa znajduje się obecnie w zbiorach Połączonych Bibliotek Wydziału Filozofii i Socjologii UW, Instytutu Filozofii i Socjologii PAN oraz Polskiego Towarzystwa Filozoficznego w Warszawie, gdzie po śmierci uczonego przekazała ją jego synowa - Elżbieta Grabska-Wallis. To właśnie wśród tych archiwaliów znajdują się także materiały poświęcone bezpośrednio Henrykowi Elzenbergowi. Są to dwie teczki (jednostki: Rps 15 i Rps 16), na które składa się około 3000 stron, głównie rękopisów, sporadycznie także maszynopisów. Zawierają one rozległy materiał historyczny (m.in. wspomnienia, recenzje, fragmenty dzieł, a także korespondencję wzajemną myślicieli), stanowiąc tym samym cenne źródło wiedzy z zakresu historii filozofii polskiej XX wieku. Wallisowskie zapiski ukazują wiele unikatowych informacji zarówno z życia osobistego Elzenberga (np. opis jego relacji rodzinnych, perypetii mieszkaniowych czy zdrowotnych), jak i tych, dotyczących jego aktywności w środowisku naukowym. Wallisowskie archiwalia poświęcone Elzenbergowi to niezwykle oryginalny zapis zarówno kilkudziesięcioletniej przyjaźni i współpracy naukowej obu myślicieli, jak i intelektualne świadectwo epoki, w której żyli i tworzyli. Ich główną domeną zaś jest to, że ukazują one Elzenberga oczami osoby, która go znała, rozumiała, akceptowała i ceniła.

\footnotetext{
${ }^{3} \mathrm{O}$ zainteresowaniach badawczych i działalności naukowej Wallisa zob. więcej w: J. Pelc, Wspomnienia pozgonne o Mieczysławie Wallisie i Tadeuszu Wójciku, „Studia Semiotyczne” 1977, nr 7, s. 5-6.

${ }^{4}$ Por. T. Pękala, Estetyka otwarta Mieczysława Wallisa, Wyd. Instytut Kultury, Warszawa 1997.
} 


\section{Przyjaźń i współpraca naukowo-badawcza Mieczysława Wallisa i Henryka Elzenberga}

Warto zaznaczyć, że znajomość obu myślicieli, która szybko przerodziła się w bliską przyjaźń, trwała od 1923 roku aż do śmierci Elzenberga w 1967 roku. Jej świadectwem są przede wszystkim listy, które słali oni do siebie nieprzerwanie przez kilka dziesięcioleci. Ich korespondencja, obejmująca lata 1929-1966, zawiera ponad 1000 stron zachowanych listów.

Początki tej niezwykle trwałej i cennej relacji Wallis wspominał po latach następująco:

Poznałem Ciebie wiosną 1923 r., ale już przedtem słyszałem o Tobie od Kotarbińskiego, Wittlina i Kołaczkowskiego. Po raz pierwszy bodaj usłyszałem Twoje nazwisko od Kotarbińskiego. Pewnego razu, gdy byłem u niego na Brzozowej, powiedział mi, że wśród młodych filozofów jednym z zapowiadających się najciekawiej jest docent Uniwersytetu Jagiellońskiego, Henryk Elzenberg. Po raz drugi usłyszałem Twe nazwisko z ust Wittlina ${ }^{5}$. Późną wiosną $1922 \mathrm{r}$. przyszedłem do niego [...], by się pożegnać przed jakimś wyjazdem. Zastałem go podnieconego, gestykulującego żywo nad zeszytem jakiegoś czasopisma. Przyczyną tego podniecenia była Twoja recenzja jego Hymnów. Recenzja była raczej ujemna, ale Wittlin ocenił od razu jej wysoki poziom, jej przenikliwość, jej subtelność. Po raz trzeci usłyszałem o Tobie od Kołaczkowskiego, który właśnie przygotowywał się do objęcia, po Borowym, „Przeglądu Warszawskiego” i widział w Tobie jeden z przyszłych filarów tego czasopisma. U Kołaczkowskiego $^{6}$ też poznałem Ciebie ${ }^{7}$.

Ze względu na to, że los rzucał Wallisa i Elzenberga w różne rejony kraju myśliciele Ci rzadko mięli sposobność obcowania ze sobą twarzą w twarz. Nie dane im było także pracować razem w jednym ośrodku akademickim. Wallis przez wiele lat pozostawał związany $\mathrm{z}$ utworzonym po wojnie Uniwersytetem Łódzkim, gdzie kierował Katedrą Estetyki, a następnie Historii

${ }^{5}$ Józef Wittlin (1896-1976), polski poeta, prozaik i tłumacz żydowskiego pochodzenia; autor powieści, esejów i utworów poetyckich. Por. E. Wiegandt, Wstęp, [w:] J. Wittlin, Sól ziemi, Zakład Narodowy im. Ossolińskich, Wrocław 1991, s. V-LXXXV.

${ }^{6}$ Wallis określał Stefana Kołaczkowskiego jako krytyka literackiego, eseistę, autora studiów o Kasprowiczu. Por. Materiały Archiwalne M. Wallisa, Archiwum Połączonych Bibliotek WFiS UW, IFiS PAN i PTF w Warszawie, teczka Rps nr 15, T. I, k. 31.

7 Tamże, teczka Rps nr 16, T. I, k. 121. 
Sztuki ${ }^{8}$, Elzenberg zaś najpierw był pracownikiem naukowym uniwersytetu w Wilnie ${ }^{9}$, później - Uniwersytetu Mikołaja Kopernika w Toruniu ${ }^{10}$. Stąd też ich przyjaźń trwała, rozwijała się i była pielęgnowana głównie na kartach korespondencji, którą przez dziesięciolecia regularnie utrzymywali. Listy oraz Wallisowskie wspomnienia dowodzą również, że co jakiś czas spotykali się ze sobą, chociażby po to, by spędzić razem wakacje (np. w Ośrodku Wczasowym w Rabce czy w słynnej willi Witkiewiczówce w Zakopanem), a także zapraszając się nawzajem do swych macierzystych ośrodków akademickich na odczyty i posiedzenia naukowe. Relacja, jaką udało im się nawiązać, była na tyle silna, bliska i trwała, że pozwoliła im wzajemnie dogłębnie się poznać i zrozumieć.

Stąd też Wallisowskie wspomnienia poświęcone Elzenbergowi stanowią cenne źródło wiedzy o życiu, osobowości, inspiracjach twórczych i zainteresowaniach naukowo-badawczych toruńskiego filozofa. Pozwalają też wyjaśnić i zrozumieć wiele znamiennych rysów jego osobowości i twórczości.

$\mathrm{O}$ wadze łączącej ich relacji Wallis pisał do toruńskiego filozofa z okazji 70 rocznicy jego urodzin następująco:

Patrząc dziś wstecz na blisko trzydzieści pięć lat naszej niczym niezmąconej przyjaźni, widzę jak wielką rolę odegrałeś w mym życiu. [...] Obcowanie intelektualne z Tobą w ciągu wielu lat, rozmowy i dyskusje o najrozmaitszych problemach filozoficznych i życiowych, wymiana wrażeń, spostrzeżeń, uwag o przeczytanych utworach literackich, oglądanych dziełach sztuki, spotykanych ludziach - wszystko to było niezmiernie doniosłym czynnikiem mego rozwoju umysłowego: $\mathrm{z}$ biegiem lat coraz bardziej zdaję sobie $\mathrm{z}$ tego sprawę ${ }^{11}$.

\footnotetext{
${ }^{8}$ Więcej na temat działalności dydaktyczno-naukowej Wallisa w okresie łódzkim zob. W. Nowakowska, Sylwetki łódzkich uczonych. Profesor Mieczysław Wallis, Łódzkie Towarzystwo Naukowe, z. 59, Łódź 2001, s. 11.

${ }^{9}$ Więcej o okresie wileńskim w życiu Elzenberga zob. W. Tyburski, Wileński okres $w$ życiu i działalności twórczej Henryka Elzenberga, [w:] Filozofia na Uniwersytecie Wileńskim, red. R. Jadczak, J. Pawlak, Wyd. UMK, Toruń 1997, s. 116.

${ }^{10}$ Okres toruński był czasem wytężonej pracy naukowo-badawczej Elzenberga, stąd też bywa on nazywany „Profesorem z Torunia”. Por. U. Schrade, Henryk Józef Maria Elzenberg, „Edukacja Filozoficzna" 1998, t. 25, s. 168.

${ }^{11}$ Tamże, k. 120.
} 
Także Elzenberg darzył swego przyjaciela ogromnym szacunkiem i zaufaniem, czego dowodem może być fakt, że to właśnie jego wybrał na opiekuna swej spuścizny twórczej po śmierci ${ }^{12}$.

Warto podkreślić, że obaj nie tylko szczerze się przyjaźnili, ale także wspierali się w swej działalności naukowo-zawodowej: przesyłali ciekawe publikacje i przekłady, opisywali swe wrażenia z konferencji naukowych, relacjonowali proces powstawania i wydawania swych dzieł, a także czynnie pomagali sobie w publikowaniu. Często też wysyłali do siebie własne dzieła z prośbą o opinię i uwagi krytyczne lub po prostu jako prezent i dowód uznania. Wymieniali się także literaturą naukową, pomagając sobie w budowaniu i rozwijaniu zaplecza i warsztatu naukowego. Relacja, jaką udało im się nawiązać, opierała się zatem zarówno na wzajemnym zrozumieniu dla swych charakterów, osobowości, postaw, jak i na uznaniu dokonań twórczych oraz naukowo-badawczych.

\section{Osobowość i inspiracje twórcze Henryka Elzenberga we wspomnieniach Mieczysława Wallisa}

Dzięki Wallisowskim wspomnieniom poznajemy Elzenberga nie tylko jako myśliciela i filozofa, ale także jako niezwykle wrażliwego, oddanego swej pracy intelektualnej człowieka o złożonej, nietuzinkowej osobowości, który w swym życiu musiał zmierzyć się z wieloma przeciwnościami losu, odrzuceniem, trudami dnia codziennego, a które nie pozostały bez wpływu na jego osobowość i psychikę. Dzięki tym wspomnieniom zatem, być może po raz pierwszy, pojawia się możliwość, by ujrzeć Elzenberga w tak wielowymiarowej perspektywie - jako intelektualistę i zarazem człowieka z krwi i kości.

W swych zapiskach Mieczysław Wallis z niezwykłą wnikliwością, obiektywizmem, a zarazem zrozumieniem i empatią diagnozuje wiele zjawisk z życia i aktywności intelektualnej Elzenberga. Na przykład opisuje przyczyny i konsekwencje towarzyszącej mu przez całe życie, a do dziś podkreślanej przez badaczy jego sylwetki twórczej - samotności, zarówno w sferze życia osobistego, jak i naukowego; cechy stanowiącej zarazem jeden $\mathrm{z}$ istotnych przyczynków do Elzenbergowskiego kultu indywidualizmu i perfekcjonizmu. Choć należy podkreślić, że autor Kłopotu z istnieniem „nie był jednak

\footnotetext{
${ }^{12}$ Por. tamże, T. III, k. 187-189.
} 
odludkiem i mizantropem. Lubił w chwilach wytchnienia wytworną towarzyskość i ożywioną, pobudzającą intelektualnie rozmowę"13. Cieszył się także uznaniem i sympatią wśród swych bliskich uczniów, współpracowników i przyjaciół (warto wymienić m.in. takie osoby, jak: T. Czeżowski, K. Górski, B. Wolniewicz, Z. Herbert, M. Kalota-Szymańska, E. Aniszczenko) ${ }^{14}$. Mógł również liczyć na niezwykle troskliwą opiekę ze strony swej bratowej, Heleny Wirskiej. Mimo to, często czuł się nie rozumiany przez otoczenie, wyobcowany i osamotniony. Być może przyczyną takiego nastawienia była jego introwertyczna osobowość i niezwykłe przeczulenie na własnym punkcie. Stąd, zdaniem Wallisa, jako człowiek ,był zamknięty w sobie, pod pewnymi względami był on zagadką nawet dla swego najbliższego otoczenia" ${ }^{\prime 1}$.

Wallis przyczyn odpowiedzialnych za taki stan rzeczy upatrywał przede wszystkim w życiu osobistym. Podkreślał, że Elzenberg czuł się osamotniony już od wczesnego dzieciństwa. Nigdy bowiem tak naprawdę nie doświadczył troski i miłości ze strony rodziców. Stracił matkę już jako niemowlę, a ojciec szybko powtórnie zawarł związek małżeński, którego owocem był drugi syn (Julian Wirski ${ }^{16}$ ). Henryk już w wieku 9 lat został wysłany na naukę do Szwajcarii pod opieką niezamężnej ciotki Anny, siostry ojca, osoby - jak podaje Wallis: „o ścisłym umyśle i bogatej gruntownej wiedzy, ale przy tym surowej, jeśli nie oschłej”" ${ }^{\prime 17}$ W wielu 13 lat stracił także ojca i, jak pisze, Wallis: „W ten sposób niemal od dzieciństwa był sierotą i nie zaznał ciepła rodzinnego domu, co później przez całe życie odczuwał jako krzywdę"18. Od wczesnej młodości towarzyszyły mu także depresyjne nastroje, miewał nawet myśli samobójcze. Ten rys osobowości odziedziczył zapewne po ojcu, który (jak

\footnotetext{
${ }_{13}$ Tamże, teczka Rps nr 15, T. I, k. 40.

${ }^{14}$ Por. U. Schrade, Szkoła Elzenbergistów, [w:] W. Mackiewicz, Ludzie i idee. Polska filozofia najnowsza, Wyd. Witmark, Warszawa 2003; Zbigniew Herbert, Henryk Elzenberg. Korespondencja, Wyd. Zeszyty Literackie, Warszawa 2002; E. Aniszczenko, Myśl namiętna i zahamowana. Rzecz o Henryku Elzenbergu, Wyd. W Kolorach Tęczy, Wrocław 1997; T. Sommer, Wolniewicz. Zdanie własne. Wywiad rzeka z najbardziej prawoskrętnym polskim profesorem filozofi, Wyd. 3S Media, Warszawa 2010; B. Wolniewicz, Myśl Elzenberga, „Studia Filozoficzne” 1986, nr 12; M. Kalota-Szymańska, Światło w ciemnościach (wspomnienie o profesorze Henryku Elzenbergu), „Studia Filozoficzne” 1986, nr 12.

${ }^{15}$ Materiały Archiwalne Mieczysława Wallisa..., teczka Rps nr 15, T. I, k. 32.

${ }^{16}$ O przyrodnim bracie Elzenberga Wallis pisał następująco: „Jego brat przyrodni, Julian Wirski, liryk i dramaturg [...] bardzo niepodobny do niego o gwałtownym temperamencie - ekspansywny, wybuchowy, niezrównoważony [...]". Tamże, k. 29.

17 Tamże, k. 11.

${ }^{18}$ Tamże, k. 5.
} 
zaświadcza w jednej z notatek Mieczysław Wallis) miewał długotrwałe stany depresji ${ }^{19}$. Być może przeżycia te wpłynęły także na jego późniejszą nieumiejętność przystosowania się do otoczenia i wchodzenia w bliskie i trwałe relacje uczuciowe. Jego jedyne małżeństwo z Wandą Radoską okazało się nieudane i zakończyło się po kilku latach rozstaniem. O charakterze tej relacji Mieczysław Wallis pisał w swych wspomnieniach następująco:

Raczej ona go zdobyła. On ze swymi skłonnościami samotniczymi nie miał, jak się zdaje, większej ochoty do tego małżeństwa. Było ono oparte na wzajemnym szacunku i sympatii, ponadto na podziwie dla Henryka ze strony Wandy, nie na pociągu zmysłowym.

W kolejnej notatce pisze też:

Henryk ożenił się z Wandą Radoską, z szanowanej i zamożnej rodziny krakowskiej pochodzenia żydowskiego [...], kobietą inteligentną [...], subtelną i wykształconą (pracowała ona w konsulacie brytyjskim w Warszawie). [...] Henryk miał wtedy 40 lat, Wanda 37. Ich przyzwyczajenia były [...] już wtedy ostatecznie sformułowane i żadne $\mathrm{z}$ nich nie umiało wyrzec się ich na rzecz drugiego. Powstawały stąd konflikty, w których po stronie Wandy stawała jej liczna i zwarta rodzina. Wanda zapadła też na rzadką chorobę krwi, co spowodowało, że Elzenberg wpadł w stan ciężkiego rozstroju nerwowego. Wandę podleczono, ale małżeństwo rozpadło się. Filozof wyjechał w 1936 roku do Wilna, a jego żona pozostała w Warszawie, zmarła podczas wojny ${ }^{20}$.

Co ważne, Elzenberg nigdy więcej nie wszedł już w żaden formalny związek natury uczuciowej, do końca życia pozostał też bezdzietny. Mimo to, choć wszelkie dotychczasowe źródła wiedzy dotyczące biografii Elzenberga milczą na ten temat, okazuje się, że w jego życiu pojawiła się jednak bliska jego sercu kobieta. Informację tę zawiera jeden z listów filozofa, który wysłał do Wallisa w 1946 roku, a więc kilkanaście lat po swym rozwodzie ${ }^{21}$. W liście tym autor z niezwykłą emfazą, egzaltacją i zapalczywością opisywał losy swego silnego, acz z góry skazanego na niepowodzenie uczucia. Co ważne, z relacji tej wynika, że choć ostatecznie uczucie to pozostało niespełnione, to było jednak w pełni odwzajemnione. Pojawia się tu z pewnością niezwykle frapujące py-

\footnotetext{
${ }^{19}$ Por. tamże, k. 41.

${ }^{20}$ Tamże.

${ }^{21}$ Warto zwrócić tu uwagę, że Elzenberg zbliżał się już do 60 roku życia.
} 
tanie, pozostające niestety, jak dotąd, bez odpowiedzi, mianowicie - kim była owa tajemnicza kobieta? W treści listu nie ma bowiem żadnych danych, które mogłyby zdradzać jej personalia. Można jedynie przypuszczać, że Wallis wiedział, o kogo chodziło. Elzenberg pisał następująco:

Moja Ania (tzn. „ona”; nie mogę o niej mówić inaczej), zapewniwszy mnie o swoich uczuciach w słowach, jakich nigdy od żadnej kobiety nie słyszałem... wyjechała za granicę na stałe. To wisiało nad naszym stosunkiem od początku; od pierwszych dni znajomości wiedziałem, że jest jakoś w zamiarach. Ale przybrało formę niespodziewanie szaloną: po przeszkoleniu we Francji chce biedactwo jechać na służbę sanitarną w koloniach. Kobiecy Heyst, - albo jeszcze gorzej: szukanie śmierci wprost. Myślę, że to nie dojdzie do skutku, bo jej własne zdrowie nie pozwoli; ale kierunek woli jest jasny. Tragizm tego życia (nie mówiłem Ci wszystkiego) przekracza wszelką miarę; to była naprawdę vas electionis ${ }^{22}$ - piękność, płomień i polot ducha i pękło jak pod jakąś klątwą mitologiczną. Teraz chce być roztrzaskane do reszty. Nie zawsze umiałem „z nią postąpić" (głupi zwrot o takim człowieku!), popełniałem błędy, nad którymi boleję, ale wątpię, czy i postępując bezbłędnie można by ją uratowaćc ${ }^{23}$.

Elzenbergowska nieumiejętność wchodzenia w trwałe i satysfakcjonujące relacje międzyludzkie odciskała swe piętno także na jego życiu zawodowym i utrudniała mu uzyskanie akceptacji i uznania środowiska akademickiego. Wallis przekonywał, że dramat toruńskiego filozofa polegał nie tylko na jego nieprzystosowaniu do otoczenia, ale był przede wszystkim wynikiem przyjęcia postawy nieprzejednanego nonkonformizmu. Łódzki uczony pisał o swym przyjacielu następująco: „Łagodny i delikatny w obcowaniu codziennym, był nieprzejednany, gdy chodziło o poglądy" ${ }^{24}$. Należy przy tym podkreślić, że Elzenberg był filozofem, którego cechowała całkowita niezależność postawy naukowej. Nie utożsamiał się on bowiem z programem żadnej szkoły czy nurtu filozoficznego ${ }^{25}$. Zdecydowanie też stawał w jawnej opozycji do programu unaukowienia filozofii, panującego w niezwykle wpływowej wówczas

\footnotetext{
22 Vas electionis: $\mathrm{z}$ łac. - „naczynie wybrane”.

${ }^{23}$ Tamże, teczka Rps nr 16, T. III, k. 32.

${ }^{24}$ Tamże, teczka Rps nr 15, T. I, k. 36. M. Wallis, Henryk Elzenberg (wspomnienie pośmiertne), „Ruch Filozoficzny” 1967, nr 2, s. 106.

${ }^{25}$ Ten rys jego postawy intelektualnej podkreśla wielu badaczy sylwetki twórczej Elzenberga, np. L. Hostyński, pisząc następująco: „Elzenberg był samotnikiem, myślicielem, dla którego jednym z najistotniejszych zadań życiowych stało się zachowanie niezależności intelektualnej i politycznej. [...] Nie stać się »psem na łańcuchu«, do końca pozostać wiernym samemu sobie
} 
szkole lwowsko-warszawskiej, z której wywodził się zresztą sam Mieczysław Wallis. Negował jej naczelne postulaty, tj.: przestrzeganie ścisłych reguł naukowych w uprawianiu filozofii, jasność, ścisłość, precyzja terminologiczna, wyraźne definiowanie pojęć, racjonalizm, antymetafizycyzm, logiczne uzasadnianie wygłaszanych twierdzeń ${ }^{26}$, stawiając w uprawianiu filozofii na intuicjonizm, antyformalizm, pozalogiczne formy wyrazu (metafora, aforyzm, poezja). Uważał bowiem, że zawężając uprawianie filozofii do przestrzegania ścisłych metod naukowych, deprecjonuje się i znacząco ogranicza wiele jej ważnych obszarów badawczych. Stanowisko filozofa scharakteryzował także sam Wallis, pisząc:

Większość myślicieli polskich okresu międzywojennego i powojennego pragnęła uczynić z filozofii naukę, dążyła do unaukowienia filozofii. Elzenberg dowodził, że jego postawa najistotniejsza nie była nigdy postawą uczonego, lecz trochę postawą artysty, przede wszystkim zaś postawą moralisty, filozofa kultury, układacza „tablic wartości”27.

Ceną za postawę intelektualnej i moralnej odrębności i zarazem nieustępliwości była głęboko odczuwana przez Elzenberga samotność. Wallis wspominał: „Wysokie wymagania moralne, jakie stawiał sobie i innym, jego [...] niechęć do ustępstw i kompromisów utrudniały mu nieraz stosunki z ludźmi, sprawiały, że był odosobniony i samotny" ${ }^{28}$.

Stąd też wynikały jego liczne zatargi i sytuacje konfliktowe $\mathrm{z}$ otoczeniem. Wallis pisał na przykład, że:

Miał on w Krakowie zatarg z profesorem Władysławem Heinrichem, który to zatarg spowodował, przynajmniej częściowo, jego przeniesienie do Warszawy (H. twierdził, że Heinrich nazbyt go eksploatował). W Warszawie znalazł się w konflikcie z warszawskim środowiskiem akademickim, z którym nie mógł znaleźć wspólnego języka. Było to chyba coś więcej niż tylko różnica stanowisk

i wyznaczonym ideałom to dewiza życiowa Elzenberga", L. Hostyński, Układacz tablic wartości, Wyd. UMCS, Lublin 1999, s. 276.

${ }^{26}$ Por. K. Twardowski, Granice puryzmu, [w:] tenże, Rozprawy i artykuły filozoficzne, Wyd. Księgarnia Książnica-Atlas, Lwów 1927, s. 215-221; R. Jadczak, Rola Kazimierza Twardowskiego w stworzeniu analitycznej szkoły filozoficznej w Polsce, „Przegląd Filozoficzny” 1988, nr 11-12, s. 139.

${ }^{27}$ Materiały Archiwalne Mieczysława Wallisa, teczka Rps nr 15, T. I, k. 34.

${ }^{28}$ Tamże, k. 80. 
filozoficznych, poglądów na świat, stylów filozofowania. On sam wyolbrzymiał i dramatyzował ten konflikt ${ }^{29}$.

Co więcej, jak wspominał dalej Wallis: „Także po wojnie, w środowisku toruńskim, nie brakło poważnych konfliktów między nim a kolegami (z Konradem Górskim, a nawet z Tadeuszem Czeżowskim)" 30 .

Jednakże towarzyszące Elzenbergowi przez całe życie poczucie wyobcowania i samotności być może było choćby częściowo także konsekwencją jego świadomego wyboru, wynikiem twórczego sposobu życia, który obrał. Wallis, prezentując swoistą diagnozę tej jego życiowej izolacji, pisał bowiem następująco:

Żył przeważnie samotnie. W swym życiu prywatnym był człowiekiem samotnym. Po części dlatego, że nie posiadał bliższej rodziny, po części dlatego, że miał głęboki uraz na punkcie swych współludzi, swych »bliźnich«, od których doznał wielu przykrości; częściowo zaś i może przede wszystkim dlatego, że do swej intensywnej pracy intelektualnej potrzebował wiele spokoju i ciszy, a to mogła mu dać tylko jeśli nie całkowita samotność, to przynajmniej daleko posunięta ustronnośćc ${ }^{31}$.

Nieprzystępność jego osobowości oraz odrębność zainteresowań naukowo-badawczych i form wyrazu twórczego skazywały go zatem na swoistą izolację, wręcz odrzucenie w świecie nauki, z których, niestety, Elzenberg zdawał sobie w pełni sprawę i które stanowiły źródło jego nieustającej frustracji. Wallis opisywał to następującymi słowy:

Miał poczucie głębokiej obcości między filozofią, panującą podówczas na uniwersytetach polskich i reprezentowaną zwłaszcza przez Łukasiewicza i Kotarbińskiego, a swymi poglądami filozoficznymi, jeszcze nie doprowadzonymi do stanu skończonego systemu, lecz już zarysowującymi się wyraźnie. W związku z tym nie widział już dla siebie widoków na karierę akademicką i szukał jakichś innych możliwości utrzymania się i zarabiania na życie ${ }^{32}$.

Sam Elzenberg w swym dzienniku, w notatce z 1931 roku, pisał o swym intelektualnym wyobcowaniu następująco:

\footnotetext{
${ }^{29}$ Tamże, k. 41.

30 Tamże, k. 41.

${ }^{31}$ Tamże, k. 40.

32 Tamże, k. 77.
} 
Moje sposoby myślenia znalazły wielu wrogów, którzy mnie za nie wykreślili z rzędu istot rozumnych. Co się na to nazłościłem, wiem dobrze; ale faktem jest, że mi ci ludzie wyświadczyli również wielką przysługę. Swoje pomysły teoretyczne traktowałem ongiś $\mathrm{w}$ młodości, $\mathrm{w}$ duchu jakby swoistego artyzmu; miało to być [...] interesujące i piękne. Uważałem za rzecz naturalną i rozumiejącą się sama przez się, że będą one w tym charakterze, gdy dojrzeją, wdzięcznie przyjęte; bo czyż życie kulturalne nie jest swobodną konkurencją kwiatów w ogrodzie? Kwiaty jeden drugiemu nie przeszkadzają i świetnie mogą żyć obok siebie. I zdziwiłem się, gdy w rezultacie spotkałem się nie tylko z oporem, lecz z zaciekłą wolą zniszczenia ${ }^{33}$.

Nieprzychylność środowiska naukowego potęgowała także w filozofie swoiste rozdarcie intelektualne. Było ono wynikiem poczucia wewnętrznego konfliktu dotyczącego odmienności pomiędzy sposobami wyrazu jego indywidualizmu twórczego i propagowanymi ówcześnie standardami uprawiania filozofii. Elzenberg głęboko przeżywał, że nie mieścił się w kanonach intelektualnych swej epoki i że w związku z tym zajmował w środowisku naukowym niszową pozycję. Towarzyszące mu wówczas odczucia podkreślał wielokrotnie w rozmowach ze swym przyjacielem. Jedną z nich Wallis wspominał, pisząc niezwykle plastycznie:

Poszliśmy na spacer i wśród sosen, wrzosowisk i piasków nadwiślańskich Henryk opowiadał mi o planowanym przez siebie dziele poświęconym teorii wartości. Kładł przy tym nacisk na to, że praca ta, ze względu na swój temat, nie może mieć tego stopnia precyzji pojęciowej i ścisłości argumentacji, jakiej wymagają od prac filozoficznych np. Łukasiewicz lub Kotarbiński; że musi ona zawierać pierwiastki „intuicyjne” i będzie przeto uważana przez tamtych myślicieli za nienaukową. Silnie podkreślał to, co go dzieli od tamtych myślicieli i co sprawia, że nie może on liczyć na ich uznanie ${ }^{34}$.

Mimo odczuwanego rozgoryczenia i braku spełnienia intelektualnego, Elzenberg nigdy nie dążył jednak do zyskania aprobaty ówczesnych intelektualistów kosztem rezygnacji z własnego, twórczego „ja”. Mimo braku odpowiedniego uhonorowania dla swych koncepcji twórczych, obcy był mu jakikolwiek intelektualny oportunizm. Jego ambicje intelektualne nie miały bowiem nic wspólnego z szukaniem poklasku za wszelką cenę, karierowiczo-

${ }^{33}$ H. Elzenberg, Kłopot $z$ istnieniem. Aforyzmy w porządku czasu, Wyd. UMK, Toruń 2002, s. 221-222.

${ }^{34}$ Materiały Archiwalne Mieczysława Wallisa, teczka Rps nr 15, T. I, k. 76. 
stwem czy nieprzejednanym dążeniem do sławy. Jak pisał Wallis: „Nie zależało mu na szerokiej popularności, na rozgłosie, na oklaskach. Bolało go jednak to, że był tak mało znany, nawet wśród polskiej elity intelektualnej”35.

Odrzucenie ze strony środowiska filozoficznego nie było jednak jedyną bolączką Elzenberga, utrudniającą mu realizację własnych zamysłów twórczych. Autor Kłopotu $z$ istnieniem wielokrotnie musiał mierzyć się także $\mathrm{z}$ trudami dnia codziennego. Jak pisał Wallis: „życie jego nie było usłane różami”" ${ }^{\text {. }}$. Wręcz odwrotnie, jego życie było: „pełne cierpienia, wyrzeczeń, frustracji. [...] przez wiele lat był zmuszony parać się belferką w szkołach średnich mieszkał w warunkach najgorszych" ${ }^{37}$. Uczony zaświadcza na przykład, że w latach dwudziestych Elzenberg zmuszony był mieszkać jakiś czas w pomieszczeniu po gimnazjalnym gabinecie dentystycznym zaadaptowanym na prowizoryczne mieszkanie. „Później [...] zajmował pokój sublokatorski na Nowym Świecie, sąsiadujący ze szkołą tańca i od wczesnego popołudnia do późnego wieczora dochodziły stamtąd ciężkie, »rąbane« uderzenia w klawisze pianina. W takich warunkach pisał on m.in. swego "Lukrecjusza«"38. Przez wiele lat borykał się także $\mathrm{z}$ wieloma dolegliwościami zdrowotnymi, zmuszającymi go do wielokrotnych pobytów w szpitalach i sanatoriach i które to, jak przekonywał Wallis, stopowały jego pracę twórczą ${ }^{39}$. Stąd też Wallis przekonywał, że afirmacja wyrzeczenia jako postawy etycznej tak charakterystyczna w twórczości Elzenberga była silnie podbudowana jego doświadczeniami osobistymi. Pisał: „nie jest przypadkiem, że czyniąc z konieczności cnotę, napisał on rozprawę "Etyka wyrzeczenia«, w której usiłował wykazać walory dodatnie wyrzeczenia [...]" ${ }^{40}$. Co więcej, życie nie oszczędzało Elzenberga także na finiszu. Jak pisał Wallis: „Zmarł po długich i ciężkich cierpieniach, w Instytucie Reumatologicznym [...] w Warszawie, dnia 6 kwietnia 1967 roku o godz. 12.40. Sekcja zwłok wykazała, że miał tumor śródpiersia" ${ }^{31}$. $\mathrm{W}$ innym miejscu podaje wprost, że przyczyną jego śmierci była choroba nowotworowa zwana szpiczakiem plazmocytowym ${ }^{42}$.

\footnotetext{
35 Tamże, k. 82.

36 Tamże, k. 69.

37 Tamże, k. 73.

${ }^{38}$ Tamże, k. 74.

${ }^{39}$ Por. tamże, k. 68.

${ }^{40}$ Tamże, k. 63.

${ }^{41}$ Tamże, k. 72.

${ }^{42}$ Tamże, k. 64.
} 
Mimo ciężkiej choroby Elzenberg do końca pozostał jednak myślicielem oddanym bez reszty swej pracy twórczej. Autor dzieła Przeżycie i wartość zaświadcza, że jeszcze u kresu swych dni, trawiony ciężką chorobą snuł plany pracy naukowo-badawczej. W notatce zatytułowanej: „Ostatni rok” Wallis pisał:

Jesienią 1966 r., między jednym pobytem w szpitalu a drugim, jeszcze planował nową pracę: czy i jakie zachodzą związki między etyką a poglądem na świat, między aksjologią a ontologią. Jeszcze dużo czytał. [...] Od stycznia 1967 r. już nie mógł czytać. Zaczęło się powolne dogorywanie. Jeszcze niekiedy miał przebłyski świadomości. Jeszcze chciał wiedzieć, co napisał o nim Tatarkiewicz w nowym wydaniu swej Historii filozofii ${ }^{43}$.

Być może postawa ta była także po części wynikiem twórczego niedosytu. Wallis zaznaczał bowiem, że:

W późniejszych latach jego życia nękało go bolesne poczucie tego, że roztrwonił swe zdolności, że niewłaściwie gospodarował swymi siłami, ograniczonymi przez ciągłą walkę z różnymi chorobami, dolegliwościami fizycznymi, że nie zrobił tego, na co może było go stać: sądzę, że myślał tutaj zwłaszcza o planowanym przez niego w latach trzydziestych, wielkim dziele, zawierającym wykład systematyczny jego teorii wartości ${ }^{44}$.

Brak uznania ze strony środowiska akademickiego oraz trudy życia codziennego wpłynęły zapewne na to, że Elzenberg wycofał się ostatecznie ze świata zewnętrznego i jego spraw do świata własnego wnętrza - własnych tworów intelektualnych, myśli, przeżyći skupił się na doskonaleniu wewnętrznym, afirmacji indywidualizmu i perfekcjonizmu jednostki ${ }^{45}$. Elzenbergowski kult indywidualizmu znalazł bezpośrednie odzwierciedlenie przede wszystkim w jego poglądach aksjologicznych. W swych rękopiśmiennych konspektach wykładów o indywidualności pisał, że: ,jedynie stany psychicz-

\footnotetext{
${ }^{43}$ Tamże, k. 65.

${ }^{44}$ Tamże, k. 68.

${ }^{45}$ Elzenberg podkreślał znaczenie i istotę afirmowanej przezeń postawy indywidualistycznej, pisząc: „Prawdziwa, mocna indywidualność ludzka jest jak gwóźdź diamentowy, wbity prosto w kosmos na wieki wieków, bez podłożonych zabezpieczających tekturek. Takimi diamentami usiane jest dno wszechistnienia, jak przestwór nocny gwiazdami; nic ich nie łączy prócz tego, że są właśnie takie mocne i wbite - i to jest ich wielkopańska wspólnota”. H. Elzenberg, Kłopot $z$ istnieniem..., s. 318 .
} 
ne jednostek i jednostki same mogą być wartościowe" ${ }^{36}$. Zbiorowość może mieć jedynie wartość dystrybutywną (np. ze względu na posiadanie wielu wartościowych członków). Podkreślał także, że stworzona przezeń postawa etyczna tzw. homo ethicus, polegająca na dążeniu do całkowitego i trwałego zbawienia od zła moralnego i obcowania ze światem wartości bezwzględnych (perfekcyjnych), także może być realizowana jedynie przez wybrane, wybitne w sferze moralnej jednostki.

Taka postawa intelektualna i zogniskowanie zainteresowań wokół kategorii wartości sprawiały, że Wallis określał go jako człowieka żyjącego „nade wszystko życiem wewnętrznym" ${ }^{\prime 7}$. To właśnie w obcowaniu z wytworami ludzkiego kunsztu intelektualnego oraz w samym procesie twórczym filozof odnajdywał prawdziwe spełnienie i radość życia. Stanowiły one bowiem swoistą kompensatę poczucia odrzucenia ze strony bliźnich, a także życiowych niepowodzeń i cierpień. Wallis pisał o tym następująco: „Zaznał on natomiast w pełni szczęścia obcowania $\mathrm{z}$ wielkimi dziełami poezji, muzyki, sztuk plastycznych i piękną przyrodą oraz radości tworzenia, radości precyzyjnego formułowania myśli, oryginalnych, głębokich i subtelnych i nadawania im skończonego kształtu słownego"48.

Wallisowskie archiwalia stanowią prawdziwą kopalnię wiedzy na temat życia i osobowości twórczej Henryka Elzenberga. Wyróżnia je wieloaspektowość i bogactwo informacji nieznanych dotąd szerszemu gronu. Oddają one także złożoność osobowości twórczej toruńskiego filozofa.

$\mathrm{Z}$ jednej strony bowiem, autor dzieła Przeżycie i wartość przedstawia Elzenberga jako intelektualnego i życiowego outsidera, o niespełnionych ambicjach, o którym pisał: „Schizotymik, introwertyk, przeczuleniec, człowiek niepraktyczny, niezaradny życiowo »nieprzystosowany«, nie umiejący »rozpychać się łokciami«", nie miał on łatwego życia, nie zrobił żadnej »kariery«, pozostał do końca życia znany tylko niewielkiej garstce intelektualistów polskich" ${ }^{49}$. Z drugiej zaś, jego zapiski kreują obraz niezwykle zaangażowanego twórczo humanisty, który mimo że borykał się z wieloma trudnymi do-

\footnotetext{
${ }^{46}$ Materiały Archiwalne H. Elzenberga, Archiwum Polskiej Akademii Nauk w Warszawie, sygn. III-181, j. teczka nr 132, k. 6.

${ }^{47}$ Materiały Archiwalne Mieczysława Wallisa..., teczka Rps nr 15, T. I, k. 37.

${ }^{48}$ Tamże, k. 38.

${ }^{49}$ Tamże.
} 
świadczeniami życiowymi, samotnością, niezrozumieniem i niedocenieniem w środowisku naukowo-akademickim, to nie ugiął się i nigdy nie zatracił swego indywidualizmu, a także wiary w wartość swych przekonań. Mimo wielu przeciwności losu, zarówno na niwie prywatnej, jak i zawodowej, filozof pozostał wierny raz obranej intelektualnej drodze i z niezwykłą konsekwencją oraz determinacją niestrudzenie realizował swe naukowe zamysły.

\section{Bibliografia}

Aniszczenko E., Myśl namiętna i zahamowana. Rzecz o Henryku Elzenbergu, Wyd. W Kolorach Tęczy, Wrocław 1997.

Czeżowski T., Henryk Elzenberg, (1887-1967), „Studia Filozoficzne” 1967, nr 3.

Czeżowski T., Henryk Elzenberg jako teoretyk etyki, „Etyka” 1969, nr 4.

Elzenberg H., Kłopot z istnieniem. Aforyzmy w porzadku czasu, Wyd. UMK, Toruń 2002.

Elzenberg H., Pisma aksjologiczne, oprac. L. Hostyński, A. Lorczyk, A. Nogal, Wyd. UMCS, Lublin 2002.

Elzenberg H., Pisma etyczne, oprac. i wstępem opatrzył L. Hostyński, Wyd. UMCS, Lublin 2001.

Elzenberg H., Próby kontaktu. Eseje i studia krytyczne, Znak, Kraków 1966.

Elzenberg H., Wartość i człowiek. Rozprawy z humanistyki i filozofii, Wyd. UMK, Toruń 1966.

Elzenberg H., Z filozofii kultury, Znak, Kraków 1991.

Elzenberg H., Z historii filozofii, Znak, Kraków 1995.

Hostyński L., Filozofia wartości Henryka Elzenberga na tle filozofii polskiej XX-lecia. międzywojennego, „Annales Universitatis Mariae Curie-Skłodowska. Studia nad polską filozofią pierwszej połowy XX wieku", Sectio I Philosophia-Sociologia 2004, vol. XXIX.

Hostyński L., The Axiological System of Henryk Elzenberg, [w:] S. Jedynak (red.), Polish Axiology: The 20th Century and beyond, Polish Philosophical Studies, V, Washington D.C. 2005.

Hostyński L., Układacz tablic wartości, Wyd. UMCS, Lublin 1999.

Jadczak R., Pawlak J. (red.), Filozofia na Uniwersytecie Wileńskim, Wyd. UMK, Toruń 1997.

Jadczak R., Rola Kazimierza Twardowskiego w stworzeniu analitycznej szkoły filozoficznej w Polsce, „Przegląd Filozoficzny” 1988, nr 11-12.

Jedynak S. (red.), Polish Axiology: The 20th Century and beyond, Polish Philosophical Studies. 
Kalota-Szymańska M., Światło w ciemnościach (wspomnienie o profesorze Henryku Elzenbergu), „Studia Filozoficzne” 1986, nr 12.

Mackiewicz W., Ludzie i idee. Polska filozofia najnowsza, Wyd. Witmark, Warszawa 2003.

Nowakowska W., Sylwetki łódzkich uczonych. Profesor Mieczysław Wallis, Łódzkie Towarzystwo Naukowe, z. 59, Łódź 2001.

Pelc J., Wspomnienia pozgonne o Mieczysławie Wallisie i Tadeuszu Wójciku, „Studia Semiotyczne" 1977, nr 7.

Pękala T., Estetyka otwarta Mieczysława Wallisa, Wyd. Instytut Kultury, Warszawa 1997.

Palacz R., Klasycy filozofii polskiej, Zachodnie Centrum Organizacji, Warszawa-Zielona Góra 1999.

Schrade U., Aksjologia formalna Henryka Elzenberga, „Studia Filozoficzne” 1986, nr 12.

Schrade U., Henryk Józef Maria Elzenberg, „Edukacja Filozoficzna” 1998, vol. 25.

Schrade U., Szkoła Elzenbergistów, [w:] W. Mackiewicz, Ludzie i idee. Polska filozofia najnowsza, Wyd. Witmark, Warszawa 2003.

Sommer T., Wolniewicz. Zdanie własne. Wywiad rzeka z najbardziej prawoskrętnym polskim profesorem filozofii, Wyd. 3S Media, Warszawa 2010.

Twardowski K., Granice puryzmu, [w:] tegoż Rozprawy i artykuły filozoficzne, Wyd. Księgarnia Książnica-Atlas, Lwów 1927.

Twardowski, K., Rozprawy i artykuły filozoficzne, Wyd. Księgarnia Książnica-Atlas, Lwów 1927.

Tyburski W., Wiśniewski R., (red.), Elzenberg - tradycja i współczesność, Wyd. Nauk. UMK, Toruń 2009.

Tyburski W., Głos do biografii twórczej Henryka Elzenberga, [w:] tegoż, Henryk Elzenberg (1887-1967). Dziedzictwo idei. Filozofia - aksjologia - kultura, Wyd. UMK, Toruń 1999.

Tyburski W. (red.), Henryk Elzenberg (1887-1967). Dziedzictwo idei. Filozofia - aksjologia - kultura, Wyd. UMK, Toruń 1999.

Tyburski W., Stan badań nad spuścizną twórcza Henryka Elzenberga, [w:] W. Tyburski, R. Wiśniewski (red.), Elzenberg - tradycja i współczesność, Wyd. Naukowe UMK, Toruń 2009.

Tyburski W., Wileński okres w życiu i działalności twórczej Henryka Elzenberga, [w:] R. Jadczak, J. Pawlak (red.), Filozofia na Uniwersytecie Wileńskim, Wyd. UMK, Toruń 1997.

Wallis M., Henryk Elzenberg (wspomnienie pośmiertne), „Ruch Filozoficzny” 1967, nr 2.

Wiegandt E., Wstęp, [w:] J. Wittlin, Sól ziemi, Wyd. Zakład Narodowy im. Ossolińskich, Wrocław 1991. 
Wolniewicz B., Filozofia i wartości. Rozprawy i wypowiedzi z fragmentami pism Tadeusza Kotarbińskiego, Wyd. WFiS UW, Warszawa 1993.

Wolniewicz B., Filozofia i wartości, t. II, Wyd. WFiS UW, Warszawa 1998.

Wolniewicz B., Filozofia i wartości, t. III, Wyd. WFiS UW, Warszawa 2003.

Wolniewicz B., Myśl Elzenberga, „Studia Filozoficzne” 1986, nr 12.

Woroniecki M., O życiu Heryka Elzenberga, „Studia Filozoficzne” 1986, nr 12.

Zbigniew Herbert Henryk Elzenberg. Korespondencja, Wyd. Zeszyty Literackie, Warszawa 2002.

\section{Archiwalia}

Materiały Archiwalne Mieczysława Wallisa Archiwum Połączonych Bibliotek WFiS UW, IFiS PAN i PTF w Warszawie, 04-38.

Materiały Archiwalne Henryka Elzenberga, Archiwum Polskiej Akademii Nauk w Warszawie, sygn. III-181.

\section{Abstract \\ Henryk Elzenberg in the Light of Unknown Archive Sources of Mieczysław Wallis}

Archive Materials of Mieczysław Wallis are in the collection of Combined Libraries of Philosophy and Sociology Faculties of the University of Warsaw, the Institute of Philosophy and Sociology of the Polish Academy of Science and the Polish Philosophical Society. There are two files (units: Rps 15 and Rps 16) devoted to Henryk Elzenberg. They contain a rich historical material, not published before and not known to many people (among others: memoirs, reviews, letters). It is a valuable source of knowledge in the field of the history of Polish philosophy. Wallis's notes provide a lot of unique informations both on Elzenberg's private life (e.g. a description of his family relations) and also his activity in the scientific community. Furthermore, they present his philosophical concepts, as well as his motions of life and adversities he had to cope with. M. Wallis's memoirs are an unusual record of the friendship and scientific co-operation of the two scholars that lasted for a few decades. Wallis's work creates also an intellectual testimony of the epoch, in which they both lived and worked.

Key words: Henryk Elzenberg, Mieczysław Wallis, archive materials, history of Polish philosophy 